IZA DP No. 5283

Globalised Labour Markets?

International Rent Sharing across 47 Countries

Pedro S. Martins

Yong Yang

October 2010 


\title{
Globalised Labour Markets? International Rent Sharing across 47 Countries
}

\author{
Pedro S. Martins \\ Queen Mary University of London, \\ CEG-IST and IZA \\ Yong Yang \\ University of Essex
}

Discussion Paper No. 5283

October 2010

\author{
IZA \\ P.O. Box 7240 \\ 53072 Bonn \\ Germany \\ Phone: +49-228-3894-0 \\ Fax: +49-228-3894-180 \\ E-mail: iza@iza.org
}

\begin{abstract}
Any opinions expressed here are those of the author(s) and not those of IZA. Research published in this series may include views on policy, but the institute itself takes no institutional policy positions.

The Institute for the Study of Labor (IZA) in Bonn is a local and virtual international research center and a place of communication between science, politics and business. IZA is an independent nonprofit organization supported by Deutsche Post Foundation. The center is associated with the University of Bonn and offers a stimulating research environment through its international network, workshops and conferences, data service, project support, research visits and doctoral program. IZA engages in (i) original and internationally competitive research in all fields of labor economics, (ii) development of policy concepts, and (iii) dissemination of research results and concepts to the interested public.
\end{abstract}

IZA Discussion Papers often represent preliminary work and are circulated to encourage discussion. Citation of such a paper should account for its provisional character. A revised version may be available directly from the author. 
IZA Discussion Paper No. 5283

October 2010

\section{ABSTRACT \\ Globalised Labour Markets? International Rent Sharing across 47 Countries $^{*}$}

We present evidence about the role of rent sharing in fostering the interdependence of labour markets around the world. Our results draw on a firm-level panel of more than 2,000 multinationals and more than 5,000 of their affiliates, covering 47 home and host countries. We find considerable evidence that multinationals share profits internationally, by paying higher wages to their workers in foreign affiliates in periods of higher profits. This occurs even across continents, and not only within Europe, as shown in earlier research. The results are robust to different tests, including a falsification exercise based on 'matched' parents. Finally, we show that different measures of the heterogeneity between parents and affiliates tend to increase rent sharing while the number of affiliates tends to decrease rent sharing, results we argue are consistent with bargaining views.

JEL Classification: J31, J41, J50

Keywords: multinationals, profit sharing, wage determination

Corresponding author:

Pedro Martins

School of Business and Management

Queen Mary, University of London

Mile End Road

London E1 4NS

United Kingdom

E-mail: p.martins@qmul.ac.uk

\footnotetext{
* We thank comments from Erling Barth, João Ejarque, Jonathan Gardner, Jonathan Haskel, Renato Páscoa, Johannes Schmieder, Rudolf Winter-Ebmer and conference participants at CAED (London) and RWI (Essen). All errors are our own.
} 


\section{Introduction}

Labour markets are influenced by a number of variables, some of which are determined abroad. Indeed, forces such as international trade have most likely played an important role in labour markets for many centuries. More recently, foreign investment - and multinationals - have become important drivers of labour market outcomes too, in particular as globalisation regained momentum in the last decade of the last century. This paper investigates one aspect of such international linkage of labour markets, namely the extent to which domestic wages are influenced by decisions taken by multinationals. In particular, we ask if multinational firms share rents across borders. This aspect not only sheds light on the general functioning of labour markets; it also studies another possible channel behind the transmission of business cycles across countries.

Most evidence on rent sharing - supranormal profits split between employers and employees - stems from within-country studies (Abowd \& Lemieux 1993, Blanchflower et al. 1996, Van Reenen 1996, Arai 2003, Martins 2009, Dobbelaere \& Mairesse 2010). These studies find without exception that industry or firm profitability increase workers' wages. However, a recent paper (Budd et al. 2005) presents evidence that rents are also shared by multinationals to their affiliates abroad. Based on firm-level data from European multinationals and their affiliates in Europe, they find significant elasticities of affiliate wages with respect to parents' profits of around 0.03, even after controlling for the profitability of the affiliate itself ${ }^{1}$

Our paper makes three contributions to this small body of literature. First, we extend the analysis of Budd et al. (2005) to a much wider set of countries. In particular we consider a variety of multinational-affiliate relationships, drawing on an extended version of their data that covers 47 countries. We believe this is a more stringent test of international rent sharing than analyses across the North American border or within Europe, given the much greater heterogeneity in labour markets and other dimensions between, say, the U.S. and China than, say, between Germany and France. Second, we conduct a number of new robustness tests, including a falsification exercise that seeks to control for the role of common shocks affecting both the parent and its affiliate. Third, we investigate some of the possible determinants of

\footnotetext{
${ }^{1}$ See also Budd \& Slaughter (2004), which finds that the influence of U.S. industry profitability on Canadian union wages depends on whether the Canadian firms have parents in the U.S. In some other papers, the 'domestic', within-country rent sharing literature also exhibits an 'international flavour', namely when the exogenous variation used to identify the rent sharing effect comes from international variables, such as exchange rates and/or international trade (Abowd \& Lemieux 1993, Martins 2009).
} 
the international rent sharing that we document, namely the role of different measures of the heterogeneity (or distance) between the parent and the affiliate.

Our results indicate that multinationals do share their profits with their affiliates abroad, even if the latter are located in a very different country. The wage elasticities we find are always precisely estimated and never below 0.01. In some cases, namely when using instruments based on lagged profits, the elasticities are as large as 0.08 , even if less precisely estimated. We also find that the geographic, economic or cultural differences between the locations of multinationals and their affiliates increase the magnitude of the rent sharing while the number of affiliates of a multinational has the opposite effect. We believe this is consistent with a bargaining interpretation of rent sharing but less so with fairness or risk sharing views. Indeed, the heterogeneity between locations can be regarded as a proxy for the complementarity between parent and affiliate in terms of the global production process of the conglomerate; and such complementarity can be assumed to increase the bargaining power of affiliates.

The next section describes the data used, after which section 3 presents the main results. Sections 4 and 5 study the robustness of the main results and the relationship between the heterogeneity of locations and rent sharing, respectively. Finally, Section 6 concludes.

\section{Data}

Our analysis draws on Orbis, a data set with detailed accounting and financial information for the largest firms across the world. The data are collected and made available by Bureau van Dijck, an international consultancy firm. According to Bureau van Dijck, the information in Orbis is sourced from company reports collected by different providers, all of which are financial experts in their regions, providing detailed information, in particular about the company financial status ${ }^{2}$

The records of each company include information on its subsidiaries or affiliates, defined as firms where the company has an ownership stake (corresponding to a minimum $25.01 \%$ shares control). These affiliates are identified by company name and country. As information

\footnotetext{
${ }^{2}$ Orbis also contains further detail such as news, market research, ratings and country reports, scanned reports, ownership and mergers and acquisitions data. There is also a large number of additional reports per company, in particular about banks, insurance and other listed companies, as well as other large private companies. On the other hand, there is unfortunately no information on workforce human capital. See Ribeiro et al. (2010) for more information on the Orbis data set and Yang \& Martins (2010) for another paper that uses this data set.
} 
on the link between the affiliate and the parent is only available for the last year in which the parent appears in the data, we assume that the two firms were linked during all years in which their information is available (Budd et al. (2005), who use the European version of these data, Amadeus, make the same assumption). Moreover, we consider firms that have information available on wage expenditure, profits, capital and employment levels. Firms that report missing variables in at least one of these variables are dropped from our analysis. This criterion leads to the exclusion of several firms in some countries, in particular Canada, Mexico and India. However, this is not a relevant problem for the overwhelming majority of countries.

Firms that report negative profits (4.9\% of all observations) are dropped, as we adopt a $\log$ transformation in our analysis, as in Budd et al. (2005). We also drop firms with less than 50 employees and outliers in average wages and profits per worker.

Given the focus of the data on large companies, the data issues reported above, and the fact that the data are relatively expensive, we were not able to obtain information about all subsidiaries of all multinationals. However, we were still able to create a large data set, covering a total of 2,179 multinational parents and 5,230 of their foreign subsidiaries, over the period 1996 to 2007 (Budd et al. (2005) cover 865 multinationals and 1919 affiliates). A total of 3,274 out of our 5,230 affiliates are located in different continents than their parents.

\subsection{Descriptive Statistics}

Table 1 presents the key summary statistics, regarding the 21,840 observations in our data set (each observation corresponds to a unique parent-afilliate-year combination). As one would expect, we find that affiliates have much smaller average workforces (1,344 vs. 41,449 employees) and much smaller average levels of sales (€0.3 vs. €9.8 million). At the same time, these numbers indicate that our data set covers as many as 29 million workers-year in affiliate firms alone. On the other hand, average profits per worker are similar in the two types of firms ( $€ 26,500$ vs. $€ 27,600)$ and average capital per worker is even higher in affiliates than multinationals (€419,600 vs. $€ 352,100)$, even if, of course, total profits and total capital are higher in multinationals, by virtue of their much larger size. Monetary values were converted into euros using exchange rates retrieved from the IMF.

In terms of the time coverage of the data, it is centered around 2002, with a small standard 
dispersion (2.7 years). Each parent-affiliate match appears on average 4.2 times (standard deviation of 2.6), which facilitates a longitudinal analysis and thereby controlling for timeinvariant (observed and unobserved) heterogeneity.

Affiliate average wages are lower than parent average wages (€40,000 vs. $€ 53,000)$. This comparison is possibly distorted by the large number of parents for which there is no data on average wages, even if this is not important in our main analysis as it does not require information on parent wages. However, when considering the subset of affiliates whose parents present wage information, the average wage is approximately $€ 38,000$, which is very similar to the previous number.

Table 2 presents the country distribution of firms, separately for multinational parents and overseas subsidiaries, along with the most important variables used in our analysis, including the average profit, capital and wage per worker. Our data cover 47 countries, including many OECD countries and also the largest developing nations - see Figure 1. Unsurprisingly, parents are concentrated in developed countries, with significant numbers in Belgium, Denmark, Finland, France, Germany, Italy, Japan, the Netherlands, Sweden, the U.K. and the U.S., which account for $83.3 \%$ of all parents. The majority of overseas subsidiaries are found in Belgium, the Czech Republic, Denmark, Finland, France, Germany, Italy, the Netherlands, Norway, Poland, Romania, Spain, Sweden and the U.K., which account for $88.8 \%$ of all overseas subsidiaries included in our data set. Unfortunately, overseas subsidiaries established in the U.S. do not include information on wages, and therefore cannot be included in our analysis, unlike U.S. multinationals.

To offer a better feel for the data, we present scatterplots of average wages and profits of affiliates and average profits of parents by affiliate country in Figure 2. The size of each circle is proportional to the number of affiliates or parents by country. The left panel indicates that higher affiliate profit is associated with larger affiliate average wage. On the other hand, the right panel (affiliate wages vs. parents profits) suggests that international rent sharing may also exist even if the relationship would be weaker than in the previous case. As a supplement to the main descriptive statistics, we also present some indicative information on the dynamics of wages and profits, based on a random sample of 50 of our affiliates - see Figure 3 . This figure depicts the variation over time of wages and profits between the first and last years in which such affiliates are present in the data. It suggests again there is a positive relationship 
between changes in affiliate (parent) profits and changes in affiliate wages, even if mean years effects were removed previously ${ }^{3}$

Finally, Figure 4 presents a tentative three-dimensional graph of the wages and profits of affiliates (horizontal and vertical axes) and the profits of parents, based on a $10 \%$ random sample of our data. The figure also includes the 'shadow' of the three-dimension dots along the horizontal plane. The patterns suggest positive correlations of affiliate wages with both affiliate and parent profits.

\section{Results}

Following Budd et al. (2005), we examine the relationship between affiliate wages and multinational profits by estimating the following equation:

$$
\text { Wage }_{i t}^{A}=\beta_{1} \operatorname{Profit}_{i t}^{P}+\beta_{2} X_{i t}+\alpha_{i}+\gamma_{t}+e_{i t},
$$

where the key variables are $\operatorname{Wage}_{i t}^{A}$, the logarithm of the average wage of affiliate $i$ in year $t$, and Profit $t_{i t}^{P}$, the logarithm of the profit of the parent of the same affiliate $i$ in the same year $t$. The equation also includes other control variables $\left(X_{i t}\right)$, namely the profit and capital of affiliates and the capital of parents (again all measured in logs), and different combinations of fixed effects, including industries (82) and countries, and year effects $\left(\gamma_{t}\right)$, the latter controlling for business cycles and wage trends. Finally, the most detailed specifications also control for affiliate fixed effects $\left(\alpha_{i}\right)$. The key parameter is $\beta_{1}$, which indicates the elasticity of affiliate wages with respect to parent profits.

Table 3 reports our first set of estimates. Columns 1 to 3 exclude parents' characteristics (as in 'within-country' studies) while columns 4 to 6 consider parents' profits and capital level. Columns 1 and 4 do not include any controls, while columns two and five control for affiliate country and industry (two-digit classification), and year effects. Finally, columns 3 and 6 control for affiliate fixed effects and year effects. From the first three columns, we find that affiliate profit and capital have the predicted positive effect upon affiliate wages. In particular, the affiliate profit result - elasticities between $3 \%$ and $4 \%$ - suggests that rent sharing also

\footnotetext{
${ }^{3}$ On the other hand, a similar figure (available upon request) no longer exhibits clear patterns between changes in the wages of parents and changes in the profits of parents or affiliates, in particular in the latter case.
} 
applies in subsidiaries of multinationals. This result is consistent with the literature that looks at samples of (domestic- and foreign-owned) firms in a given country Abowd \& Lemieux 1993 , Blanchflower et al. 1996, Van Reenen 1996, Arai 2003, Martins 2009).

Turning to the last three columns of Table 3, we find that parent profits also have a positive and significant effect upon affiliate wages, even when already controlling for affiliate profits and capital (and parent capital). The elasticities range between 3\% and $1 \%$ and are always precisely estimated. The latter, smaller estimate (1\%) arises in the most demanding specification, which draws on the longitudinal variation of affiliate wages and parent profits, after controlling for year fixed effects (and longitudinal variation in parent capital and affiliate profits and capital).

While the affiliate fixed effects used above control for time-invariant heterogeneity, it remains possible that our estimates suffer from a simultaneity or endogeneity bias. For instance, parents and affiliates may suffer from demand shocks that occur at the same time and that could facilitate the misleading interpretation of an effect from parent profits to affiliate wages. In order to solve or at least alleviate this issue, we draw on a instrumental variables approach, using lagged values of profits to instrument for current-period parent profits. As before, we also control for firm fixed effects and other variables.

Table 4 reports the results, for different specifications, namely no controls (column 1), sector and year fixed effects (column 2) and affiliate and year fixed effects (column 3). The estimates of the wage-parent profit elasticities range between $5 \%$ and $8 \%$ (the upper bound arising in the most detailed specification) and are always significant, at least at the $10 \%$ level. The lagged profit per worker also displays a significant and positive effect, as expected. Moreover, the Sargan test of over-identification indicates that the instruments are valid.

One could argue that our sample of affiliates and parents is not representative of the country distribution of foreign direct investment in the world and this could distort our findings. To shed light on this matter, we rerun the models of Table 3 but now weighting each observation using alternately the levels of FDI of the parent country or of the host country (using data from UNCTAD). This concern does not appear to be relevant given that the new estimates presented in Table 5- are very similar. In particular, the most detailed specification (column 6) again indicates elasticities of around $1 \%$.

We also tested the robustness of these IV results to the consideration of host or home 
country FDI weights and we found no qualitative differences. The same applies to specifications ignoring parent or affiliate capital or affiliate profits. In terms of our OLS results, we also found that the results are robust to a log-level specification, that does not force us to drop observations with negative profits. We also compared the rent sharing estimates between manufacturing and services and found very similar results in the two cases. When comparing the estimates between developed countries and from developed to developing economies, we found that the latter point estimates tend to be larger, a result that we address in more detail in Section 5. All these addtional findings are available upon request. . $^{4}$

A useful measure of the economic effect of international rent sharing is the Lester range (Lester 1952). This is defined as the wage increase of a worker that would move from a 'lowrent' firm to a 'high-rent firm', while everything else were constant, in which 'low (high) rent' is defined as the rent level two standard deviations below (above) the mean. Focusing on the last three columns of Table 3, we find Lester ranges of 7\% (in our most detailed specification) to $19 \%$ (corresponding to column 4). When considering instead the GMM estimates from Table 4, as expected Lester ranges are much wider, from $30 \%$ to $47 \%$. These latter estimates are also similar to the equivalent results obtained in Budd et al. (2005), which reports a central Lester range of $36 \%$.

\section{Further robustness}

\subsection{Affiliate-to-parent rent sharing?}

Our first robustness test involves examining if there are rent-sharing effects when considering again the relationship between parents and affiliates but from the opposite direction, i.e. if affiliates share rents with parents' employees. Given the much larger size of multinational parents when compared to affiliates (as indicated in Section 2.1), we would find it surprising if such affiliate-to-parent rent sharing also occurred. Furthermore, such a result could cast doubts on our interpretation of the main results, as it could suggest that the parent-to-affiliate rent sharing arose out of common shocks to the two firms rather than a genuine outcome of

\footnotetext{
${ }^{4}$ We are also currently working on a companion paper where we draw on matched employer-employee panel data for one of the countries considered in the study which we then also match to information about the parent's profitability. This exercise allows one to consider human capital differences in much greater detail, including sources of heterogeneity such as worker-level time-invariant heterogeneity and firm-worker match effects. However, this comes at the expense of international generality.
} 
bargaining or risk-sharing mechanisms.

We test this hypothesis drawing on a modified version of equation 2

$$
\operatorname{Wage}_{i t}^{P}=\beta_{1} \operatorname{Profit}_{i t}^{A}+\lambda X_{i t}+\alpha_{i}+\gamma_{t}+e_{i t},
$$

where $W a g e_{i t}^{P}$ is the log of the average wage of multinational parent $i$ in year $t$ and Prof $_{i t}^{A}$ refers to the log of the profit of the affiliate over the same period. The equation also includes other control variables, including the profit and the capital of the parent and the capital of affiliate $\left(X_{i t}\right)$, parent industry, country or firm fixed effects $\left(\alpha_{i}\right)$ and business cycle effects $\left(\gamma_{t}\right)$. The key parameter is $\beta_{1}$, which indicates the elasticity of parent wages to affiliate profits.

Table 6 presents the results, following a similar structure to Tables 3 and 5 . Columns 1 to 3 , which ignore affiliate variables, indicate that rent sharing is present at the multinational (parent) level - a result that is similar to the one obtained when considering the role of affiliate profits on affiliate wages. On the other hand, the symmetry with previous findings is shown to come to an end when we consider the role of affiliate profits on parent wages (columns 4 to 6): except for the simplest specification (column 4), the other results indicate no significant evidence of rent sharing from affiliates to their parents. As before, we find that these results are robust (i.e. still insignificant) to different weightings.

We also conducted another test following a similiar approach, in which we examine the relationship between the employment levels of affiliates and the profits of their parents. If increasing parents' profits lead to the expansion of the size of the affiliates, then the average affiliate wage could increase if marginal workers demand higher individual wages, and not because of rent sharing. However, we could not find any systematic link between parent's profits and affiliate size. These results are available upon request.

\subsection{Falsification test}

As mentioned before, one concern about our preferred interpretation of the international rent sharing results is that it may arise out of shocks that simultaneously hit the profitability of parents and the wage levels of affiliates. For instance, a worldwide increase in the demand for a given product could presumably raise the profits of a multinational that operates in that industry while, at the same time, that shock will also raise the labour demand - and therefore the wages - of workers of an affiliate of that same multinational based in a different country. 
Even if this alternative explanation is less likely to apply in the context of our more diverse set of multinationals and affiliates, compared to Budd et al. (2005), this correlation could be strong enough to survive the controls we consider, leading us to incorrectly interpret our results as rent sharing.

In order to provide additional evidence on this issue, on top of the IV and affiliate-toparent analyses presented before, here we conduct the following falsification test: we match parents to other parents that are very similar in a number of characteristics (as available in our data set), in the spirit of a propensity score matching analysis (Rosenbaum \& Rubin 1983). Furthermore, we also require that each parent and its match (another parent) are located in the same industry and in the same country (i.e. we exact match on these two variables) $5_{5}^{5} \mathrm{We}$ then take the profit information of this 'matched parent' and use that in the regression in the place of the profit information of the true parent. Finally, we rerun our previous estimations, based again on the benchmark specification of equation 1 .

The idea is to select information from parent firms that are very similar and therefore would be subject to the same shocks as the matched counterpart. If this exercise results in similar or at least significant estimates of 'rent sharing', then we would have to at least revisit our interpretation of our previous estimates (such as those of Table 3). On the other hand, if this exercise results in insignificant estimates, then that would be consistent with our preferred interpretation of rent sharing.

The range of variables initially available for the matching exercise is reasonably large (employment, sales, capital, age, number of affiliates, year), and certainly at least comparable to ranges adopted in other empirical papers. In any case, we also consider several transformations of these variables (squares, cubes, interactions of two and three variables) in order to obtain a more precise correspondence between the two matched parents, at least along observable dimensions, in the spirit of a propensity score matching exercise. As mentioned above, we also require that, for each affiliate, the matched parent is in the same industry and country as the original, true parent. To provide more robustness, we also obtain results when we match on the parents' profits on top of the remaining variables.

As to the matching process itself, we start by pooling all parents and affiliates and then estimate a logit model where the dependent variable is a parent dummy and the regressors

\footnotetext{
${ }^{5}$ Ideally, we would be matching Coca-cola and Pepsi or HP and Dell, for instance.
} 
are the variables and polynomials described above. Using these coefficients, we compute the probability that each parent is in fact a parent (the alternative being an affiliate). In the last step of this analysis, we find which parent is the best match for each other parent by comparing their probabilities of 'parenthood', as in the nearest neighbour algorithm.

Table 7 presents descriptive statistics on the quality of the match obtained. These variables are measured in ratios as those of the employment flows literature, which are bound between -2 and +2 (i.e. we divide the difference of the two figures by the mean of the same two figures). The results indicate a very good quality in the matching, as the average ratios are always low - even if the standard deviations are relatively high. Furthermore, we find that matching also on profits does not change teh results, in particular it does not lead to a sizable deterioration of the quality of matching, which is further evidence that our matched parents are similar to the original parents. The absence of major differences to the quality of matching when profits are added is driven by the very large number of variables used in the matching process (more than 60 variables).

The regression results - presented in Table 8- are again based on different versions of equation 1. Moreover, the first set of estimates (columns 1 to 3 ) weights each observation inversely to the absolute difference in the propensity score of the parent and its match. In other words, these results attach greater importance to parents that are better matched. The top panel, where profits are ignored as a matching variable, indicate evidence of spurious rent sharing only when not controlling for any covariates (columns 1 and 4). In the remaining columns, all 'parent' profits estimates are insignificant. Some point estimates are even negative. The bottom panel exhibits greater resilience of the spurious rent sharing effects, as expected: even the columns with industry and country fixed effects return significantly positive coefficients. However, when adding affiliate fixed effects (columns 3 and 6), the coefficients again lose significance and the point estimates are virtually zero.

We take the results from this novel test as important evidence against a spurious relationship between parent profits and affiliate wages and in a favour of a causal interpretation of our findings. 


\section{Extensions}

Having provided considerable evidence of a causal interpretation of our estimates, we now turn to the fit between our results and the theoretical motivation presented above, which was based on bargaining and risk sharing mechanisms. We test this fit by making the argument that, if bargaining and/or risk sharing do in fact drive the rent sharing results presented in the paper, then the 'heterogeneity' between the parent and the affiliate - which may be proxied by the countries where they are located - may be an important parameter affecting the magnitude of the effect.

For instance, if the parent and the affiliate are located in nearby or even adjacent countries, then it is less likely that they will be subject to different shocks that would warrant a risk sharing mechanism. Furthermore, if the parent and affiliate are located far away from each other, then it may be more likely that the type of foreign investment that occurred there is of a vertical nature (Carr et al. 2001), if the multinational is slicing its production chain to explore the location advantages of the affiliate country. In that case, this will have implications in terms of a stronger bargaining power of the affiliate, as the scope of hold-up and of disruption of the international production flow would increase. However, in the case of horizontal investment, a threat by an affiliate to stop or disrupt production would have much smaller knock-on consequences in terms of the multinational production process, even in a period of increasing profits, given its weaker complementarity with the parent. In this case, the scope for wage increases would be small.

These mechanisms are also consistent with evidence that multinationals take into account local market conditions when setting up foreign operations, for instance by focusing affiliates on processing imported inputs (vertical investment) in countries with lower wages and trade costs and smaller markets (Hanson et al. 2005). As the latter type of countries will be found mostly in developing countries, while multinationals typically have their headquarters in developed economies, then, if rent sharing is relevant, the wages of affiliates in developing countries will be more closely tied to the circumstances of headquarters than the wages of affiliates in developed economies. This may be particularly important in a context of contract incompleteness (Ottaviano \& Turrini 2007).

In our empirical analysis of this issue, we take a broad approach to the concept of 'heterogeneity' of parent and affiliate locations. In particular, we consider geographic, economic, 
technological, and linguistic (cultural) measures. From the discussion above, we take these measures of heterogeneity as proxies for the degree of complementarity and for the potential of risk sharing between the affiliate and the parent. We also consider a variable that seeks to capture the complementarity of the two types of firms more directly - a dummy variable equal to one if the two firms operate in the same industry. However, even such a measure does not capture the concept that we are examining, as differences within a two-digit industry classification may already be enough to generate important complementarity issues.

More specifically, the list of heterogeneity variables that we use in this extension is as follows:

1. Economic development: the GDP per capita difference between the country where the parent is located and the country where the affiliate is located, using GDP data from the World Development Indicators (World Bank 2010).

2. Intellectual property rights (IPR): computed from the difference in the Park (2008) IPR index for each one of the two countries. Given the data available (2000 and 2005 only), we use the 2000 IPR index for the years corresponding to 1997-2000 and the 2005 IPR index for the years corresponding to 2001-2007.

3. Technology: difference in the share of resident patent applications in the total number of applications in the two countries, as available from the World Bank indicators, given that patent data are often used as a measure of technological capability (Griliches 1990).

4. Language: dummy variable equal to one if the two countries have the same official language and zero otherwise.

5. Geography: distance (log kilometers) between the capital cities of parent and affiliate country, following the 'great circle formula', as available from the CEPII Distances dataset.

6. Industry: dummy variable equal to one, if the two firms are in the same two-digit industry, or zero, otherwise.

This empirical analysis draws on a subset of our main data of multinational parents (and their affiliates) that have overseas affiliates in at least in two different countries. The reason for imposing this restriction is that, as we need to compare rent sharing across locations, 
single-affiliate parents would not be informative in this respect. The descriptive statistics of the new data set are in Table 9. we find that the number of observations falls from 21,840 to 16,223 with this restriction but, apart from that, the average firm characteristics of the two versions of the data set hardly change. As to the heterogeneity variables, we find that, for instance, $19 \%$ of the parent-affiliate pairs operate in countries that have the same main language and $8 \%$ operate in the same two-digit industries ${ }^{6}$

We estimate the effects of heterogeneity in terms of the rent sharing between parents and affiliates by adding each variable and its interaction with the affiliate profits variable in equation 3

Wage $_{i t}^{A}=\beta_{1}$ Profit $_{i t}^{P}+\beta_{2}$ Heterogeneity $_{i t}+\beta_{3}$ Profit $_{i t}^{P} *$ Heterogeneity $y_{i t}+\lambda X_{i t}+\alpha_{i}+\gamma_{t}+e_{i t}$,

All variables have the same interpretation as before, while Heterogeneity $y_{i t}$ corresponds to each one of the six heterogeneity variables we consider and Profit $_{i t}^{P} *$ Heterogeneity $_{i t}$ is the interaction term of interest. However, in order to compare the effects of each heterogeneity variable, we standardise them. Specifically, we subtract the mean of the variable across all observations used and then divide that difference by the standard deviation of the variable again obtained across all observations considered.

The results are presented in Tables 10 (no weights) and 11 (weights based on parent country FDI) $]^{7}$ First of all, we find that the heterogeneity variables have the predicted effect on affiliate wages. Regardless of the table, affiliate wages are lower the farther away they are from the parent country in terms of economic development, technology, IPR or geography. The same applies to language (positive coefficient if the language is the same), while the 'same sector' status is associated with smaller average wages.

Turning now to the key results, those of the interaction terms, three of the six coefficients are significant in Table 10 while five are significant in Table 11, and the sign of the point estimates is always the same in the two tables. We find that rent sharing increases with virtually all our measures of heterogeneity. For instance, the greater the economic gap between the countries of the parent and the affiliate, the stronger the rent sharing between the two firms.

\footnotetext{
${ }^{6}$ If we were considering only parents and affiliates based in Europe, as in Budd et al. (2005), IPR average distance would fall from 0.15 to 0.04 , economic distance would fall from 7,666 to 6,257 and geographic distance would fall from 3,487 to 926 (standard deviations would also fall similarly). However, the same sector dummy would increase from 0.08 to 0.12 .

${ }^{7}$ Results based on weights by host country FDI are very similar and available upon request.
} 
Similarly, rent sharing is weaker between firms in countries that share the same language. The magnitude of the effects is also similar across measures 8

The only exception to this pattern concerns geographic distance, whose coefficient is insignificant in both tables. This result is consistent with one of the robustness tests presented in Budd et al. (2005), who also interacted profits with geographic distance. They justify this analysis arguing that rent sharing could be determined by information flows, and the latter could be proxied by physical location. However, they found "no substantial variation in profit sharing from distance" (p. 81). In our view, one could argue instead that geographic distance is a poor proxy for the idea of complementarity between locations as a determinant of rent sharing that motivates our analysis.

Overall, these results may also be consistent with recent findings based on matched firmworker longitudinal data that the wage premium of foreign-owned firms with respect to domestic firms is decreasing in the level of development of the host country (Hijzen et al. 2010).9 $9^{9}$ If foreign-owned firms in developing countries benefit from high levels of rent sharing (as predicted from our distance results), then rent sharing would create a wedge, on average, between the pay levels of the two types of firms. This would still be the case even if base wages were initially set at similar levels to those of domestic firms in those countries. A similar wedge would not arise, at least not to the same extent, between domestic and foreign firms in developed countries given the smaller levels of heterogeneity, on average, with respect to the parent countries of the latter.

Finally, we investigate a little deeper the bargaining interpretation of our results by considering a new interaction: the number of affiliates of each parent. The motivation is that, if a parent has many affiliates, it will be more difficult for any one of them to extract wage concessions from the parent through rent sharing. All being the same, an affiliate of a parent company with a large total number of affiliates would have weaker bargaining power as it would not be able to threaten to disrupt the operation of the parent to the same extent as an affiliate of a smaller parent (with fewer affiliates). In the former case, a multinational could rellocate production across the world ('footloose multinationals') and even play affiliates one

\footnotetext{
${ }^{8} \mathrm{We}$ also found that rent sharing increases with the difference in the level of 'intangible capital' between the parent and the affiliate. However, we have not been able to obtain a good definition of the measurement of such capital in our data.

${ }^{9}$ In current work in progress, we also find considerable evidence, drawing on a similar data set to the one used in this paper, of a negative relationship between economic development and wage differentials between domestic and foreign firms (Martins \& Yang 2010).
} 
against the other.

In terms of the descriptive statistics, we do find considerable levels and dispersion of the number of parent affiliates across affiliates: 196 on average and a standard deviation of 191 (see Table 9). These numbers are quite large as they draw together home and overseas affiliates, including foreign affiliates not picked up in our data set but that are owned by a parent. The statistics are also computed across affiliates, which will give greater weight to large parents. Moreover, the results in Tables 10 and 11 indicate clearly that rent sharing falls with the number of affiliates: the point estimates of the interaction coefficients are -0.012 and -0.028 (columns 7). We take these results as additional evidence that bargaining mechanisms drive the rent sharing effects that we document, rather than risk sharing of fairness considerations ${ }^{10}$

\section{Conclusions}

The paper examined the extent to which multinationals share their rents across affiliates located abroad in terms of higher affiliate wages, considering a wide variety of home and host countries. This is an important question to understand the sensitivity of domestic labour markets to economic conditions abroad and the mechanisms behind the international transmission of shocks. Until now, this issue had been examined only in Budd et al. (2005), who draw on 1990s data of multinationals and affiliates based in Europe.

Here we draw on firm-level panel data that is similar to the one used in that paper except that it covers a larger and more heterogeneous range of parent-affiliate pairs. Many of these parent-affiliate pairs are located in different continents and in very different country settings, along several dimensions. We can therefore not only assess the generality of the international rent-sharing phenomenon but also understand some of its determinants, namely in terms of the contrast between the locations of the parent and affiliate firms, with a view to clarifying its theoretical mechanisms.

First, we find that the earlier results for multinationals and affiliates both located in Europe (Budd et al. 2005) also hold when considering a wide set of both parent and affiliate locations. We obtained elasticities of average affiliate wages with respect to parent profits of $1 \%$ to $8 \%$, the latter case when considering instrumental variables.

\footnotetext{
${ }^{10}$ We also discussed this paper with two senior human resource managers from two large multinationals (based in the consultancy and pharmaceuticals sectors), who find our results and the bargaining interpretation consistent with their personal experiences.
} 
Second, we obtain evidence that such a positive relationship is particularly robust and consistent with a causal interpretation. For instance, affiliate profits do not seem to affect parent wages. This is as one would expect given the smaller size of affiliates - but not necessarily if a third, unobservable variable were driving both profits and wages of the two types of firms, such as common shocks to parents' profits and affiliate's wages. More important, our falsification exercise, based on considering the profits of similar parents, resulted in insignificant estimates.

Third, when examining the determinants of international rent sharing, we find that location heterogeneity (regardless of its specific definition - economic, geographic, cultural, technological) tends to predict stronger rent-sharing effects. On the other hand, the number of affiliates reduced rent sharing. We argue that this result supports the view that rent sharing is driven by bargaining considerations. Indeed, such heterogeneity can be regarded as a proxy for complementarities in production (vertical foreign investment), which would create bargaining opportunities.

\section{References}

Abowd, J. \& Lemieux, T. (1993), 'The effects of product market competition on collective bargaining agreements: The case of foreign competition in Canada', Quarterly Journal of Economics 108, 983-1014.

Arai, M. (2003), 'Wages, profits and capital intensity: Evidence from matched worker-firm data', Journal of Labor Economics 21, 593-618.

Blanchflower, D., Oswald, A. \& Sanfey, P. (1996), 'Wages, profits and rent-sharing', Quarterly Journal of Economics 111, 227-252.

Budd, J. W., Konings, J. \& Slaughter, M. J. (2005), 'Wages and international rent sharing in multinational firms', Review of Economics and Statistics 87, 73-84.

Budd, J. W. \& Slaughter, M. J. (2004), 'Are profits shared across borders? Evidence on international rent sharing', Journal of Labor Economics 22, 525-552.

Carr, D. L., Markusen, J. R. \& Maskus, K. E. (2001), 'Estimating the knowledge-capital model of the multinational enterprise', American Economic Review 91(3), 693-708. 
Dobbelaere, S. \& Mairesse, J. (2010), Micro-evidence on rent sharing from different perspectives, NBER Working Paper 16220.

Griliches, Z. (1990), 'Patent statistics as economic indicators: a survey.', Journal of Economic Literature 28, 1661-1707.

Hanson, G. H., Mataloni, R. J. \& Slaughter, M. J. (2005), 'Vertical production networks in multinational firms', Review of Economics and Statistics 87(4), 664-678.

Hijzen, A., Martins, P. S., Schank, T. \& Upward, R. (2010), Do foreign-owned firms provide better working conditions than their domestic counterparts? A comparative analysis, IZA DP 5259 .

Lester, R. (1952), 'A range theory of wage differentials', Industrial and Labor Relations Review 5, 483-500.

Martins, P. S. (2009), 'Rent sharing before and after the wage bill', Applied Economics 41, 2133-2151.

Martins, P. S. \& Yang, Y. (2010), Foreign wage differentials around the world, Queen Mary, University of London mimeo.

Ottaviano, G. I. P. \& Turrini, A. (2007), 'Distance and foreign direct investment when contracts are incomplete', Journal of the European Economic Association 5(4), 796-822.

Park, W. (2008), 'International patent protection: 1960 to 2005', Research Policy 37, 761-766.

Ribeiro, S. P., Menghinello, S. \& Backer, K. D. (2010), The OECD ORBIS database: Responding to the need for firm-level micro-data in the OECD, OECD Statistics Working Papers 2010/1.

Rosenbaum, P. \& Rubin, D. (1983), 'The central role of the propensity score in observational studies for causal effects', Biometrika $\mathbf{7 0}, 41-55$.

Van Reenen, J. (1996), 'The creation and capture of rents: Wages and innovation in a panel of U.K. companies', Quarterly Journal of Economics 111, 195-226.

World Bank (2010), World development indicators, Report. 
Yang, Y. \& Martins, P. S. (2010), Firm performance and the geography of FDI: Evidence from 46 countries, CGR WP 30. 


\section{Figures}

Figure 1: Country coverage

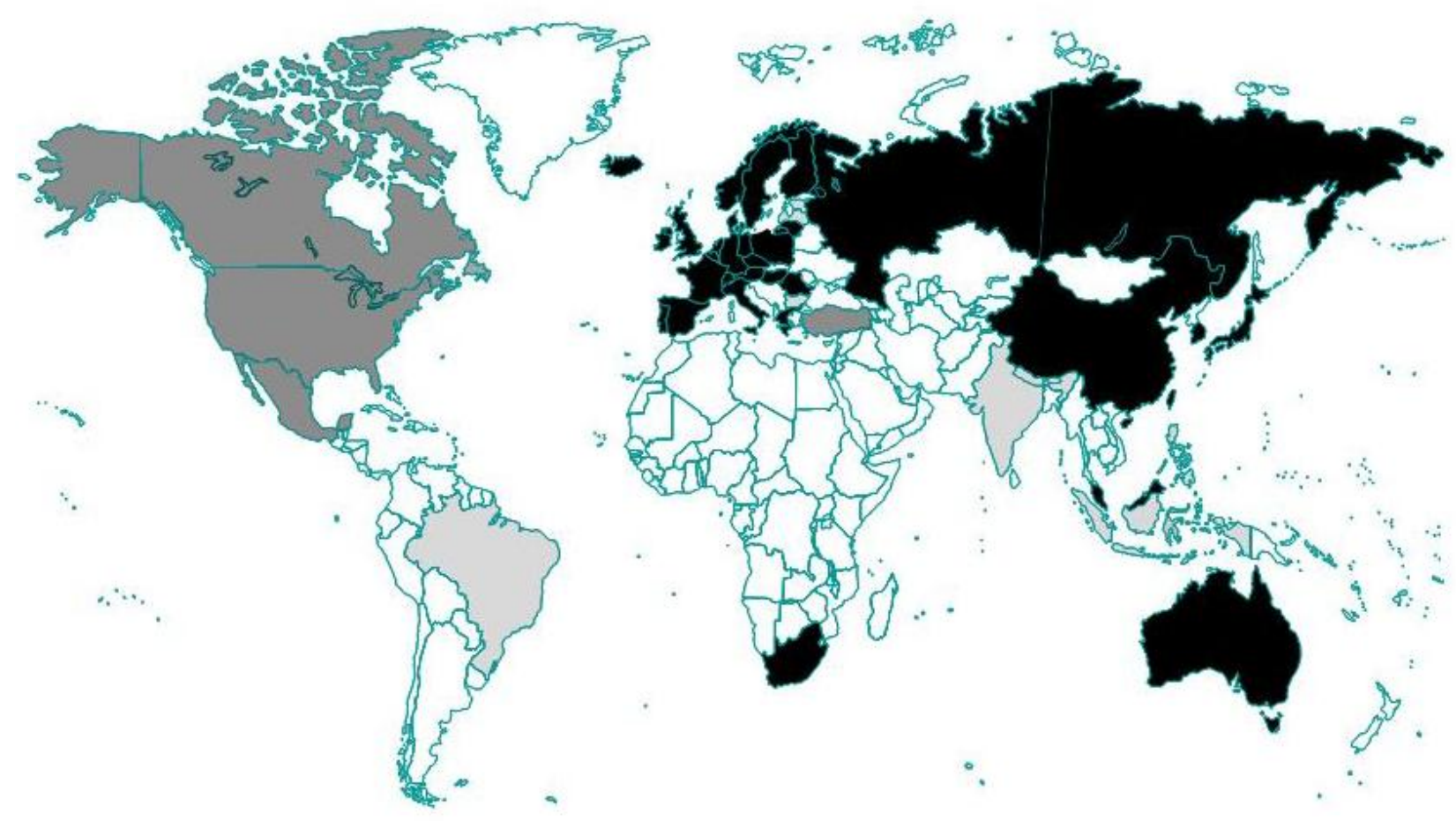

Notes: There are four groups of countries, depending on the type of information available in our data set: countries for which we have both parent and affiliate information (in black), only parent information (dark grey), only affiliate information (light grey), no information (white). The first three categories include 47 countries. 
Figure 2: Average wages and profits of affiliates and average profits of parents, by country
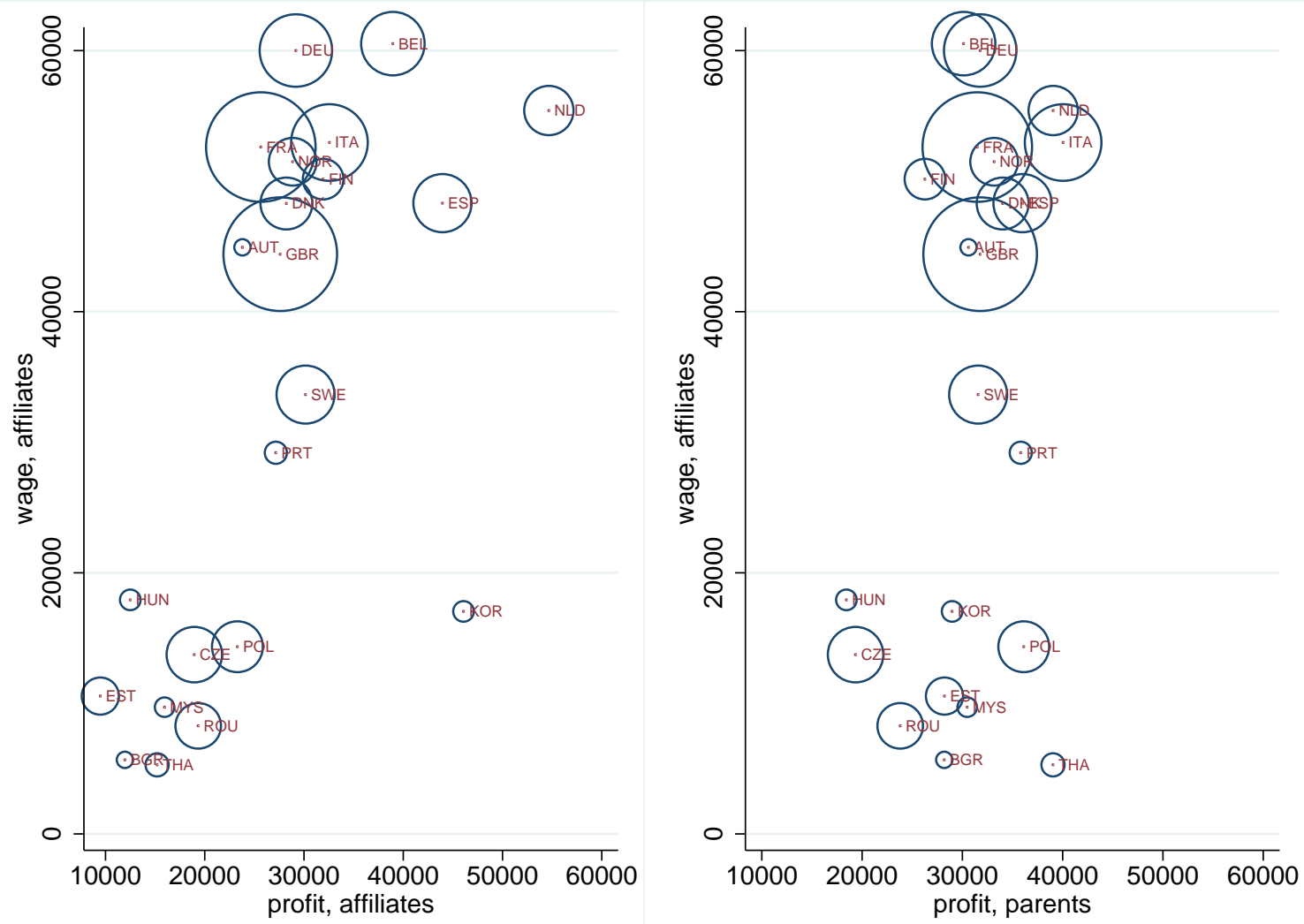

Notes: The left figure is the relationship between affiliate profit (average) and affiliate wage (average), by country in the year of 2005. Countries with more than 10 firms are left in this figure. The right figure is the relationship between parent profit (average) and affiliate wage (average), by country. Size of circle is proportional to the weight of GDP per capita of 2005 by country. Weight is used from world development indicator. The label in the circle is the country ISO code. Countries included in this figure are Australia (AUS), Austria (AUT), Belgium (BEL), Bulgaria (BGR), Brazil (BRA), Switzerland (CHE), China (CHN), the Czech Republic (CZE), Germany (DEU), Denmark (DNK), Spain (ESP), Estonia (EST), Finland (FIN), France (FRA), the U.K. (GBR), Greece (GRC), Hong Kong (HKG), Hungary (HUN), Indonesia (IDN), Indian (IND), Ireland (IRL), Iceland (ISL), Italy (ITA), Japan (JPN), South Korea (KOR), Liechtenstein (LIE), Lithuania (LTU), Luxembourg (LUX), Latvia (LVA), Malaysia (MYS), the Netherlands (NLD), Norway (NOR), Philippines (PHL), Poland (POL), Portugal (PRT), Romania (ROU), Russia (RUS), Singapore (SGP), Slovenia (SVN), Sweden (SWE), Thailand (THA), Taiwan (TWN), and South Africa (ZAF). Taiwan is not included in the figure as GDP per capita is not available from world development indicator. 
Figure 3: Wage of affiliates (start/end years), profit of affiliates (start/end years) and profit of parents (start/end years)
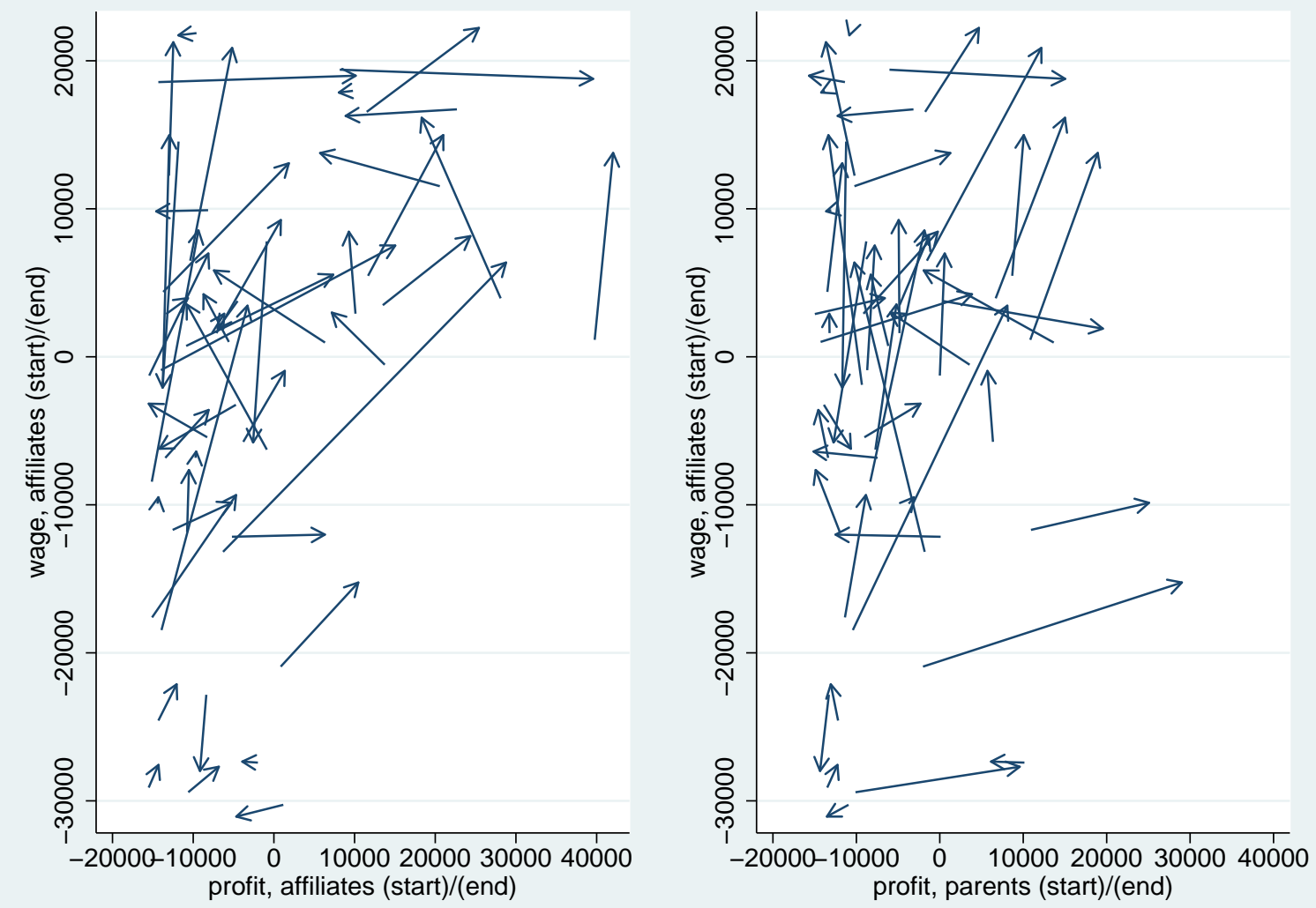

Notes: We randomly sample 50 firms from our data (number of firms we sampled are not too big to make the figure clear). The left figure depicts the relationship between affiliate profit (start/end year) and affiliate wage (start/end year). The right figure is the relationship between parent profit (start/end year) and affiliate wage (start/end year). Considering most points exhibit an increase over time, we regressed the variable on year dummies, take the residuals, and then depict the above figure. 
Figure 4: Scatterplot of wage of affiliates, profit of affiliates and profit of parents

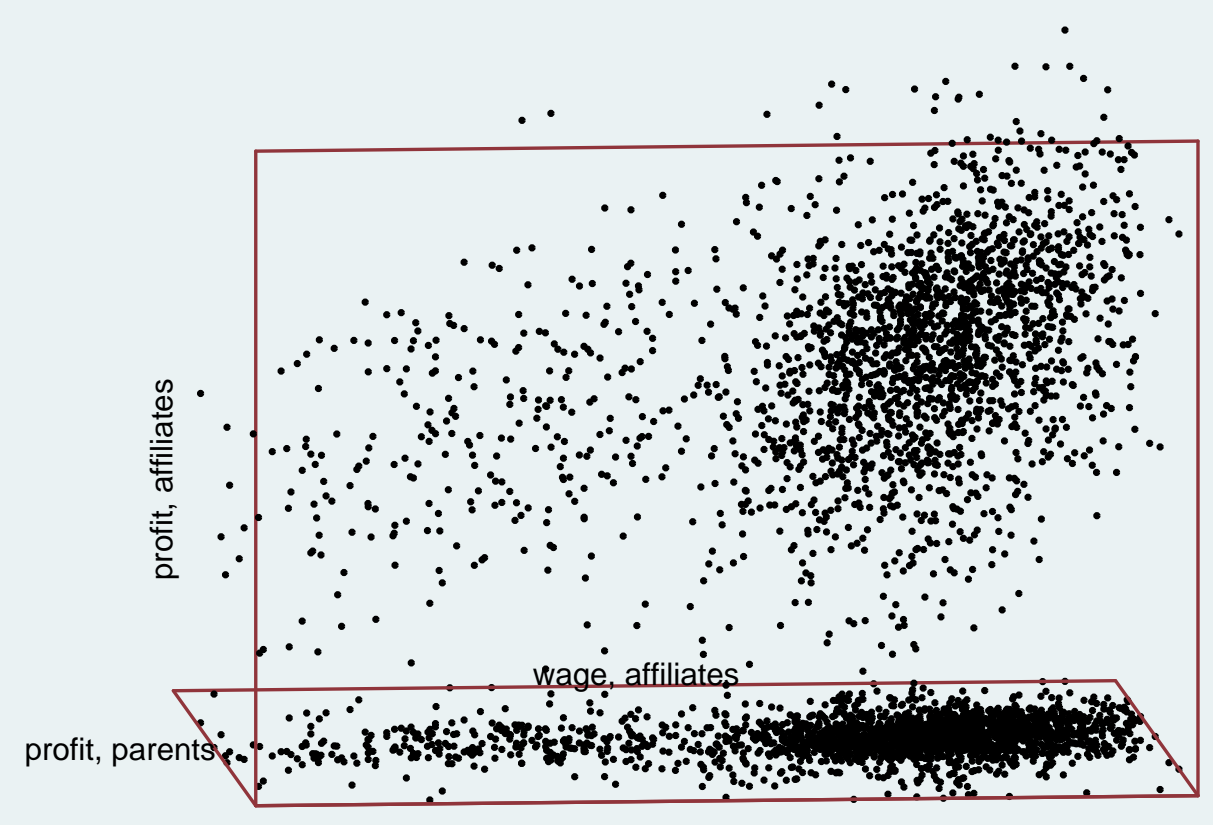

Notes: The above figure is three-dimensional graph of wage of affiliates, profit of affiliates and profit of parents. We randomly sample $10 \%$ firms from our data to make the figure clear. The horizontal x-axis presents wage per worker of the affiliates. The horizontal y-axis presents profit per worker of the parents. The vertical axis presents profit per worker of the affiliates. This figure also include the shadow that instead of vertical spikes from the data points to the $(\mathrm{x}, \mathrm{y})$ plane, each data point (red color) is paired with a shadow point (blue color) on the $(\mathrm{x}, \mathrm{y})$ plane. 


\section{Tables}

Table 1: Descriptive statistics

\begin{tabular}{llccc}
\hline \hline \multirow{4}{*}{ Affiliates } & Variables & Mean & Std. Dev. & Obs \\
& Average wage per worker & 40.0 & 20.6 & 21840 \\
& Profit per worker & 26.5 & 41.1 & 21840 \\
& Capital per worker & 419.6 & 13487.6 & 21840 \\
& Employment & 1344.8 & 4788.7 & 21840 \\
& Turnover & 347337.9 & 1006446 & 21821 \\
& & & & \\
Parents & & & \\
& Average wage per worker & 53.3 & 621.5 & 12624 \\
& Profit per worker & 27.6 & 42.8 & 21840 \\
& Capital per worker & 352.1 & 804.4 & 21840 \\
& Employment & 41449.3 & 69625.7 & 21840 \\
& Turnover & 9826596 & $2.19 \mathrm{e}+07$ & 21838 \\
& & & \\
& Survey Year & 2002.3 & 2.7 & 21840 \\
\hline \hline
\end{tabular}

Notes: All monetary variables are in thousands of euros. 'Profit per worker, parents (affiliates)' is profit per worker of the multinational parents (affiliates). 'Capital per worker, parents (affiliates)' is capital per worker of the multinational parents (affiliates). 'Employment, parents (affiliates)' is number of employees of multinational parents (affiliates). 'Sales, parents (affiliates)' is total sales of the multinational parents (affiliates). 'Average wage, parents (affiliates)' is average wage per worker of the multinational parents (affiliates). 
Table 2: Number of firms and key variables per country

\begin{tabular}{|c|c|c|c|c|c|c|c|c|}
\hline \multirow[b]{2}{*}{ Country } & \multicolumn{4}{|c|}{ Affiliates } & \multicolumn{4}{|c|}{ Parents } \\
\hline & N. & Profit & Capital & Wage & N. & Profit & Capital & Wage \\
\hline Australia & 20 & 29.43 & 309.53 & 24.17 & 20 & 36.74 & 907.51 & 32.38 \\
\hline Austria & 47 & 16.94 & 289.34 & 45.15 & 28 & 21.72 & 257.57 & 46.78 \\
\hline Belgium & 279 & 32.44 & 1822.3 & 56.08 & 97 & 23.24 & 545.01 & 49.84 \\
\hline Brazil & 5 & 46.38 & 614.06 & 6.53 & 0 & & & \\
\hline Bulgaria & 35 & 6.03 & 64.73 & 4.68 & 0 & & & \\
\hline Canada & 0 & & & & 3 & 94.13 & 1231.48 & \\
\hline China & 15 & 16.72 & 215.44 & 4.75 & 2 & 2.28 & 53.83 & \\
\hline Czech Republic & 194 & 15.55 & 112.73 & 11.18 & 2 & 16.13 & 266.2 & 11.11 \\
\hline Denmark & 178 & 21.82 & 248.02 & 45.68 & 78 & 21.65 & 251.09 & 40.48 \\
\hline Estonia & 97 & 6.79 & 56.23 & 8.5 & 0 & & & \\
\hline Finland & 132 & 28.96 & 226.93 & 43.68 & 85 & 20.75 & 257.06 & 38.07 \\
\hline France & 900 & 25.1 & 311.08 & 49.53 & 142 & 31.5 & 669.78 & 52.75 \\
\hline Germany & 381 & 31.35 & 356.98 & 58.45 & 154 & 22.88 & 257.96 & 47.7 \\
\hline Greece & 2 & 14.45 & 189.17 & 24.83 & 15 & 23.51 & 237.08 & 34.39 \\
\hline Hong Kong & 4 & 18.36 & 338.67 & 9.43 & 2 & 15.81 & 142.52 & 9.03 \\
\hline Hungary & 39 & 12.98 & 138.18 & 16.98 & 4 & 16.99 & 141.38 & 11.53 \\
\hline Iceland & 2 & 89.11 & 512.57 & 52.96 & 5 & 5.96 & 224.85 & 32.99 \\
\hline India & 15 & 5.69 & 54.83 & 4.18 & 0 & & & \\
\hline Indonesia & 11 & 8.47 & 55.54 & 3.66 & 0 & & & \\
\hline Ireland & 5 & 99.97 & 543.68 & 37.82 & 21 & 32.14 & 309.38 & 36.93 \\
\hline Italy & 467 & 27.97 & 374.96 & 43.5 & 112 & 24.92 & 374.36 & 41.92 \\
\hline Japan & 13 & 41.83 & 304.91 & 43.38 & 161 & 25.77 & 542.1 & 40.6 \\
\hline Latvia & 5 & 4.47 & 61.79 & 8.74 & 0 & & & \\
\hline Liechtenstein & 1 & 4.28 & 52.7 & 33.79 & 1 & 9.85 & 120.43 & 42.58 \\
\hline Lithuania & 1 & 3.39 & 71.45 & 5.77 & 2 & 0.36 & 22.19 & \\
\hline Luxembourg & 21 & 26.72 & 748.2 & 39.23 & 10 & 36.38 & 1050.83 & 53.1 \\
\hline Malaysia & 23 & 15.58 & 142.34 & 10.06 & 8 & 21.48 & 299.58 & 8.42 \\
\hline Mexico & 0 & & & & 1 & 41.55 & 455.3 & \\
\hline Netherland & 201 & 48.35 & 697.49 & 51.52 & 203 & 20.28 & 373.69 & 45.07 \\
\hline Norway & 149 & 23.76 & 202.99 & 46.24 & 38 & 45.65 & 425.59 & 49.61 \\
\hline Philippines & 5 & 13.67 & 125.74 & 4.47 & 0 & & & \\
\hline Poland & 193 & 17.09 & 149.7 & 11.48 & 7 & 17.42 & 361.04 & 28.56 \\
\hline Portugal & 84 & 27 & 261.2 & 26.42 & 11 & 25.67 & 368.61 & 24.02 \\
\hline Romania & 130 & 10.15 & 71.01 & 5.59 & 1 & 0.78 & 145.57 & 11.97 \\
\hline Russia & 1 & 23.62 & 101.4 & 10.56 & 5 & 13.53 & 86.7 & 6.17 \\
\hline Singapore & 20 & 11.99 & 166.86 & 13.62 & 15 & 21.87 & 363.25 & 19.4 \\
\hline Slovenia & 9 & 21.56 & 256.06 & 24.75 & 2 & 12.14 & 97.83 & 14.77 \\
\hline South Africa & 6 & 10.55 & 83.55 & 10.25 & 8 & 11.48 & 185.8 & 27.37 \\
\hline South Korea & 33 & 47.55 & 292.95 & 15.54 & 2 & 58.67 & 304.97 & \\
\hline Spain & 249 & 34.05 & 377.97 & 42.05 & 66 & 44.14 & 501.96 & 39.21 \\
\hline Sweden & 208 & 26.53 & 293.03 & 29.75 & 144 & 22.08 & 252.44 & 138.79 \\
\hline Switzerland & 20 & 30.42 & 332.28 & 49.42 & 70 & 19.7 & 226.33 & 39.84 \\
\hline Taiwan & 16 & 24.62 & 197.4 & 13.84 & 10 & 12.68 & 357.12 & 14.95 \\
\hline Thailand & 30 & 11.97 & 125.96 & 4.99 & 2 & 7.2 & 135.46 & 3.72 \\
\hline Turkey & 0 & & & & 3 & 48.57 & 263.8 & 5.44 \\
\hline UK & 984 & 25.62 & 344.52 & 38.27 & 182 & 22.52 & 331.8 & 41.37 \\
\hline US & 0 & & & & 457 & 24.38 & 243.27 & \\
\hline
\end{tabular}

Notes: 2,179 multinational parents and 5,230 overseas affiliates. 'Profit' ('Capital', 'Wage') refers to average profits (capital, wages) per worker. All monetzy variables in thousands of euros. 
Table 3: Main rent sharing results

\begin{tabular}{lcccccc}
\hline \hline & $(1)$ & $(2)$ & $(3)$ & $(4)$ & $(5)$ & $(6)$ \\
\hline Profit, parents & & & & $.030^{* * *}$ & $.016^{* * *}$ & $.011^{* * *}$ \\
& & & & $(.005)$ & $(.003)$ & $(.003)$ \\
Capital, parents & & & & $-.089^{* * *}$ & $\left(.012^{* * *}\right.$ & $.091^{* * *}$ \\
& & & & $(.007)$ & $(.004)$ & $(.009)$ \\
Profit, affiliates & $.027^{* * *}$ & $.041^{* * *}$ & $.035^{* * *}$ & $.024^{* * *}$ & $.039^{* * *}$ & $.034^{* * *}$ \\
& $(.004)$ & $(.003)$ & $(.003)$ & $(.004)$ & $(.003)$ & $(.003)$ \\
Capital, affiliates & $.405^{* * *}$ & $.177^{* * *}$ & $.308^{* * *}$ & $.429^{* * *}$ & $.171^{* * *}$ & $.292^{* * *}$ \\
& $(.007)$ & $(.005)$ & $(.012)$ & $(.007)$ & $(.005)$ & $(.012)$ \\
Obs. & 21840 & 21840 & 21840 & 21840 & 21840 & 21840 \\
$F$ statistic & 2933.652 & 246.219 & 533.601 & 1501.145 & 245.621 & 352.496 \\
$R^{2}$ & .352 & .783 & .939 & .358 & .784 & .94 \\
\hline \hline
\end{tabular}

Notes: Dependent variable: log average wage per worker of multinational affiliates. All explanatory variables are in logs. Columns 2 and 5 include country, sector and year effects, while columns 3 and 6 include affiliate firm fixed effects and year fixed effects. 'Profit, affiliates (parents)' is profit per worker of the multinational affiliates (parents). 'Capital, affiliates (parents)' is capital per worker of the multinational affiliates (parents). Values in parentheses are standard errors. Robust standard errors. Significance levels: *: 0.10; **: 0.05; ***: 0.01. 
Table 4: Rent sharing: IV estimates

\begin{tabular}{|c|c|c|c|}
\hline & $(1)$ & $(2)$ & $(3)$ \\
\hline Profit, parent & $\begin{array}{c}.078^{* * *} \\
(.010)\end{array}$ & $\begin{array}{c}.053^{* * *} \\
(.007)\end{array}$ & $\begin{array}{l}.083^{*} \\
(.049)\end{array}$ \\
\hline Capital, parent & $\begin{array}{c}-.096^{* * *} \\
(.011)\end{array}$ & $\begin{array}{c}-.012^{*} \\
(.007)\end{array}$ & $\begin{array}{c}-.083^{* *} \\
(.038)\end{array}$ \\
\hline Profit, affiliate & $\begin{array}{c}.012^{* *} \\
(.006)\end{array}$ & $\begin{array}{c}.041^{* * *} \\
(.004)\end{array}$ & $\begin{array}{c}.027^{* * *} \\
(.006)\end{array}$ \\
\hline Capital, affiliate & $\begin{array}{c}.383^{* * *} \\
(.007)\end{array}$ & $\begin{array}{c}.187^{* * *} \\
(.005)\end{array}$ & $\begin{array}{c}.280^{* * *} \\
(.035)\end{array}$ \\
\hline Obs. & 10819 & 10819 & 9956 \\
\hline$F$ statistic & 1572.406 & 266.736 & 185.254 \\
\hline$R^{2}$ & .368 & .755 & .351 \\
\hline \multicolumn{4}{|l|}{ First-stage results } \\
\hline Profit per worker, parents (1st lag) & $\begin{array}{c}.569^{* * *} \\
(.009)\end{array}$ & $\begin{array}{c}.550^{* * *} \\
(.009)\end{array}$ & $\begin{array}{c}.133^{* * *} \\
(.024)\end{array}$ \\
\hline Profit per worker, parents (2nd lag) & $\begin{array}{c}.120^{* * *} \\
(.009)\end{array}$ & $\begin{array}{c}.122^{* * *} \\
(.009)\end{array}$ & $\begin{array}{c}-.088^{* * *} \\
(.021)\end{array}$ \\
\hline Hansen J statistic & 1.714 & 0.001 & 0.379 \\
\hline Chi-sq(1) p-value & .190 & .974 & .538 \\
\hline
\end{tabular}

Notes: Dependent variable: log wage per worker of affiliate. All explanatory variables are in logarithms. Values in parentheses are standard errors. 'Profit, parents' is profit per worker of the multinational parents. 'Capital, parents' is capital per worker of the multinational parents. 'Profit, affiliates' is profit per worker of the multinational affiliates. 'Capital, affiliates' is capital per worker of the multinational affiliates. 'L. Profit, parent' and 'L2. Profit, parent' are used as instruments for current-period parent profit. 'L. Profit, parents' is profit per worker of the multinational parents at one year before, and 'L2. Profit, parents' refers to profit per worker of the multinational parents at two years before. Column 1 does not control for any fixed effect, and column 2 controls for country, sector and business cycle effects. and column 3 controls for affiliate firm fixed effect and business cycle effect. Significance levels: *: $0.10 ; * *: 0.05 ; * * *: 0.01$. 
Table 5: Rent sharing - weights based on parent or host country FDI

\begin{tabular}{|c|c|c|c|c|c|c|}
\hline & $(1)$ & $(2)$ & $(3)$ & $(4)$ & $(5)$ & (6) \\
\hline \multicolumn{7}{|c|}{ Weights based on host country FDI } \\
\hline Profit, parents & & & & $\begin{array}{c}.040^{* * *} \\
(.006)\end{array}$ & $\begin{array}{c}.023^{* * *} \\
(.003)\end{array}$ & $\begin{array}{c}.011^{* * *} \\
(.003)\end{array}$ \\
\hline Capital, parents & & & & $\begin{array}{c}-.060^{* * *} \\
(.008)\end{array}$ & $\begin{array}{c}.026^{* * *} \\
(.004)\end{array}$ & $\begin{array}{c}.120^{* * *} \\
(.007)\end{array}$ \\
\hline Profit, affiliates & $\begin{array}{c}.026^{* * *} \\
(.005)\end{array}$ & $\begin{array}{c}.045^{* * *} \\
(.002)\end{array}$ & $\begin{array}{c}.035^{* * *} \\
(.002)\end{array}$ & $\begin{array}{c}.022^{* * *} \\
(.005)\end{array}$ & $\begin{array}{c}.042^{* * *} \\
(.002)\end{array}$ & $\begin{array}{c}.033^{* * *} \\
(.002)\end{array}$ \\
\hline Capital, affiliates & $\begin{array}{c}.380^{* * *} \\
(.009)\end{array}$ & $\begin{array}{c}.167^{* * *} \\
(.004)\end{array}$ & $\begin{array}{c}.302^{* * *} \\
(.006)\end{array}$ & $\begin{array}{c}.391^{* * *} \\
(.010)\end{array}$ & $\begin{array}{c}.155^{* * *} \\
(.004)\end{array}$ & $\begin{array}{c}.281^{* * *} \\
(.006)\end{array}$ \\
\hline Obs. & 21809 & 21809 & 21809 & 21809 & 21809 & 21809 \\
\hline$F$ statistic & 1496.661 & 141.465 & 2015.893 & 769.95 & 142.326 & 1122.261 \\
\hline$R^{2}$ & .328 & .75 & .929 & .332 & .753 & .93 \\
\hline \multicolumn{7}{|c|}{ Weights based on parent country FDI } \\
\hline Profit, parents & & & & $\begin{array}{c}.026^{* * *} \\
(.005)\end{array}$ & $\begin{array}{c}.016^{* * *} \\
(.003)\end{array}$ & $\begin{array}{c}.014^{* * *} \\
(.003)\end{array}$ \\
\hline Capital, parents & & & & $\begin{array}{c}-.047^{* * *} \\
(.007)\end{array}$ & $\begin{array}{c}.019^{* * *} \\
(.004)\end{array}$ & $\begin{array}{c}.091^{* * *} \\
(.006)\end{array}$ \\
\hline Profit, affiliates & $\begin{array}{c}.026^{* * *} \\
(.004)\end{array}$ & $\begin{array}{c}.036^{* * *} \\
(.002)\end{array}$ & $\begin{array}{c}.030^{* * *} \\
(.002)\end{array}$ & $\begin{array}{c}.023^{* * *} \\
(.004)\end{array}$ & $\begin{array}{c}.033^{* * *} \\
(.002)\end{array}$ & $\begin{array}{c}.029^{* * *} \\
(.002)\end{array}$ \\
\hline Capital, affiliates & $\begin{array}{c}.330^{* * *} \\
(.006)\end{array}$ & $\begin{array}{c}.172^{* * *} \\
(.003)\end{array}$ & $\begin{array}{c}.280^{* * *} \\
(.005)\end{array}$ & $\begin{array}{c}.341^{* * *} \\
(.007)\end{array}$ & $\begin{array}{c}.163^{* * *} \\
(.003)\end{array}$ & $\begin{array}{c}.264^{* * *} \\
(.005)\end{array}$ \\
\hline Obs. & 21756 & 21756 & 21756 & 21756 & 21756 & 21756 \\
\hline$F$ statistic & 2429.61 & 148.253 & 1962.027 & 1237.335 & 147.467 & 1085.128 \\
\hline$R^{2}$ & .311 & .73 & .929 & .314 & .731 & .93 \\
\hline
\end{tabular}

Notes: Dependent variable: $\log$ average wage per worker of multinational affiliate. Columns 2 and 5 above include country, sector and business cycle effects. Columns 3 and 6 above include affiliate firm fixed effects and business cycle fixed effects. 'Profit, affiliates (parents)' is profit per worker of the multinational affiliates (parents). 'Capital, affiliates (parents)' is capital per worker of the multinational affiliates (parents). Values in parentheses are standard errors. Significance levels: *: $0.10 ; * *: 0.05 ; * * *: 0.01$. 
Table 6: Rent sharing: affiliate profits on parent wages

\begin{tabular}{lcccccc}
\hline \hline & $(1)$ & $(2)$ & $(3)$ & $(4)$ & $(5)$ & $(6)$ \\
\hline Profit, affiliates & & & & $.016^{* * *}$ & .002 & .0009 \\
& & & & $(.004)$ & $(.003)$ & $(.002)$ \\
Capital, affiliates & & & & $.016^{* * *}$ & $.017^{* * *}$ & -.0004 \\
& & & & $(.005)$ & $(.004)$ & $(.003)$ \\
Profit, parents & -.008 & $.015^{* * *}$ & $.027^{* * *}$ & $-.014^{* * *}$ & $.014^{* * *}$ & $.027^{* * *}$ \\
& $(.005)$ & $(.004)$ & $(.004)$ & $(.005)$ & $(.004)$ & $(.004)$ \\
Capital, parents & $.290^{* * *}$ & $.284^{* * *}$ & $.230^{* * *}$ & $.281^{* * *}$ & $.276^{* * *}$ & $.230^{* * *}$ \\
& $(.006)$ & $(.005)$ & $(.009)$ & $(.007)$ & $(.005)$ & $(.009)$ \\
& & & & & & \\
Obs. & 12563 & 12563 & 12563 & 12563 & 12563 & 12563 \\
$F$ statistic & 1657.662 & 111.041 & 233.95 & 903.372 & 109.225 & 204.685 \\
$R^{2}$ & .282 & .551 & .852 & .287 & .552 & .852 \\
\hline \hline
\end{tabular}

Notes: Dependent variable for each regression is wage per worker of multinational parents in all columns. Second and fifth columns above include country, sector and business cycle effects, while third and sixth columns above include a full set of fixed effects, include parent firm fixed effect and business cycle effect. Values in parentheses are standard errors. 'Profit, parents' is profit per worker of the multinational parents. 'Capital, parents' is capital per worker of the multinational parents. 'Profit, affiliates' is profit per worker of the multinational affiliates. 'Capital, affiliates' is capital per worker of the multinational affiliates. Significance levels: *: $0.10 ; * *: 0.05 ; * * *: 0.01$. 
Table 7: Descriptive statistics - quality of parent matches

\begin{tabular}{lccc}
\hline \hline Variables & Obs & Mean & Std. Dev. \\
\hline Panel A: benchmark & & & \\
& & & \\
Employees difference & 1448 & -0.022 & 1.045 \\
Capital (per worker) difference & 1448 & -0.005 & 0.936 \\
Profit (per worker) difference & 1448 & -0.014 & 1.109 \\
Sales difference & 1448 & -0.024 & 1.064 \\
Age difference & 1442 & 0.007 & 1.026 \\
Subsidiary difference & 1448 & -0.021 & 0.589 \\
Same sector & 1448 & 1.000 & 0.000 \\
Same country & 1448 & 1.000 & 0.000 \\
Same year & 1448 & 0.335 & 0.472 \\
Probability difference & 1448 & -0.001 & 0.028 \\
& & & \\
\hline Panel B: matching also on profits & & & \\
& & & \\
Employees difference & 1446 & -0.023 & 1.048 \\
Capital (per worker) difference & 1446 & -0.004 & 0.940 \\
Profit (per worker) difference & 1446 & -0.014 & 1.106 \\
Sales difference & 1446 & -0.023 & 1.065 \\
Age difference & 1440 & 0.010 & 1.038 \\
Subsidiary difference & 1446 & -0.020 & 0.590 \\
Same sector & 1446 & 1.000 & 0.000 \\
Same country & 1446 & 1.000 & 0.000 \\
Same year & 1446 & 0.344 & 0.475 \\
Probability difference & 1446 & -0.001 & 0.028 \\
\hline \hline
\end{tabular}

Notes: The 'difference' variables are measured in terms of a rate, defined as the ratio between 1) the difference between the value of the variable for the original parent and the matched parent, and 2) the mean of the two values. These ratios are therefore bound between -2 and +2 . The 'same' variables (sector, country, year) are dummies equal to one if the variable takes the same value in the original and matched parents. 'Probability difference' corresponds to the difference between the probabilities of being an affiliate of the original and matched parents. 
Table 8: Falsification test: Rent sharing based on 'matched parents'

\begin{tabular}{|c|c|c|c|c|c|c|}
\hline \multicolumn{7}{|c|}{ Panel A: benchmark } \\
\hline Profit, 'parents' & $\begin{array}{c}.019^{* *} \\
(.009)\end{array}$ & $\begin{array}{l}.004 \\
(.005)\end{array}$ & $\begin{array}{l}-.009 \\
(.007)\end{array}$ & $\begin{array}{l}.021^{* *} \\
(.009)\end{array}$ & $\begin{array}{l}.004 \\
(.005)\end{array}$ & $\begin{array}{l}-.008 \\
(.007)\end{array}$ \\
\hline Capital, 'parents' & $\begin{array}{c}-.079^{* * *} \\
(.011)\end{array}$ & $\begin{array}{c}-.025^{* * *} \\
(.007)\end{array}$ & $\begin{array}{r}-.005 \\
(.014)\end{array}$ & $\begin{array}{c}-.079^{* * *} \\
(.011)\end{array}$ & $\begin{array}{c}-.025^{* * *} \\
(.007)\end{array}$ & $\begin{array}{l}-.011 \\
(.015)\end{array}$ \\
\hline Profit, affiliates & $\begin{array}{c}.018^{* *} \\
(.007)\end{array}$ & $\begin{array}{c}.035^{* * *} \\
(.004)\end{array}$ & $\begin{array}{c}.037^{* * *} \\
(.005)\end{array}$ & $\begin{array}{l}.016^{* *} \\
(.007)\end{array}$ & $\begin{array}{c}.035^{* * *} \\
(.004)\end{array}$ & $\begin{array}{c}.037^{* * *} \\
(.005)\end{array}$ \\
\hline Capital, affiliates & $\begin{array}{c}.426^{* * *} \\
(.010)\end{array}$ & $\begin{array}{c}.205^{* * *} \\
(.006)\end{array}$ & $\begin{array}{c}.358^{* * *} \\
(.011)\end{array}$ & $\begin{array}{c}.425^{* * *} \\
(.010)\end{array}$ & $\begin{array}{c}.204^{* * *} \\
(.006)\end{array}$ & $\begin{array}{c}.347^{* * *} \\
(.011)\end{array}$ \\
\hline Obs. & 8994 & 8994 & 8994 & 8994 & 8994 & 8994 \\
\hline No. Parents & 1179 & 1179 & 1179 & 1179 & 1179 & 1179 \\
\hline No. affiliates & 2835 & 2835 & 2835 & 2835 & 2835 & 2835 \\
\hline$F$ statistic & 633.731 & 52.753 & 193.646 & 642.059 & 51.727 & 184.758 \\
\hline$R^{2}$ & .357 & .766 & .927 & .352 & .764 & .925 \\
\hline \multicolumn{7}{|c|}{ Panel B: matching also on profits } \\
\hline Profit, 'parents' & $\begin{array}{c}.029^{* * *} \\
(.009)\end{array}$ & $\begin{array}{c}.016^{* * *} \\
(.005)\end{array}$ & $\begin{array}{l}-.003 \\
(.007)\end{array}$ & $\begin{array}{c}.032^{* * *} \\
(.009)\end{array}$ & $\begin{array}{c}.017^{* * *} \\
(.005)\end{array}$ & $\begin{array}{l}-.001 \\
(.007)\end{array}$ \\
\hline Capital, 'parents' & $\begin{array}{c}-.094^{* * *} \\
(.011)\end{array}$ & $\begin{array}{c}-.035^{* * *} \\
(.007)\end{array}$ & $\begin{array}{l}-.001 \\
(.015)\end{array}$ & $\begin{array}{c}-.092^{* * *} \\
(.012)\end{array}$ & $\begin{array}{c}-.034^{* * *} \\
(.007)\end{array}$ & $\begin{array}{l}-.006 \\
(.015)\end{array}$ \\
\hline Profit, affiliates & $\begin{array}{c}.015^{* *} \\
(.007)\end{array}$ & $\begin{array}{c}.035^{* * *} \\
(.004)\end{array}$ & $\begin{array}{c}.037^{* * *} \\
(.005)\end{array}$ & $\begin{array}{c}.014^{* *} \\
(.007)\end{array}$ & $\begin{array}{c}.035^{* * *} \\
(.004)\end{array}$ & $\begin{array}{c}.037^{* * *} \\
(.005)\end{array}$ \\
\hline Capital, affiliates & $\begin{array}{c}.428^{* * *} \\
(.010)\end{array}$ & $\begin{array}{c}.206^{* * *} \\
(.006)\end{array}$ & $\begin{array}{c}.357^{* * *} \\
(.011)\end{array}$ & $\begin{array}{c}.427^{* * *} \\
(.010)\end{array}$ & $\begin{array}{c}.205^{* * *} \\
(.006)\end{array}$ & $\begin{array}{c}.343^{* * *} \\
(.011)\end{array}$ \\
\hline Obs. & 8964 & 8964 & 8964 & 8964 & 8964 & 8964 \\
\hline No. Parents & 1188 & 1188 & 1188 & 1188 & 1188 & 1188 \\
\hline No. affiliates & 2831 & 2831 & 2831 & 2831 & 2831 & 2831 \\
\hline$F$ statistic & 623.711 & 53.323 & 191.2 & 636.627 & 52.268 & 180.511 \\
\hline$R^{2}$ & .355 & .769 & .927 & .351 & .768 & .926 \\
\hline
\end{tabular}

Notes: Dependent variable: log of wage per worker in each affiliate. Columns 1-3 impose weights (inverse of the absolute difference in the propensity scores of the true and matched parent). Columns 2 and 5 include country, sector and year effects. Columns 3 and 6 include affiliate firm fixed effects and business cycle fixed effects. 'Profit, affiliates (parents)' is profit per worker of the multinational affiliates (parents). 'Capital, affiliates (parents)' is capital per worker of the multinational affiliates (parents). Significance levels: *: 0.10; **: $0.05 ; * * *: 0.01$. 
Table 9: Descriptive statistics, multinationals with foreign affiliates in at least two countries

\begin{tabular}{|c|c|c|c|c|c|}
\hline & & Variable & Mean & Std. Dev. & Obs \\
\hline \multicolumn{6}{|l|}{ Firm characteristics } \\
\hline & \multicolumn{5}{|l|}{ Affiliates } \\
\hline & & Average wage per worker & 40.9 & 20.6 & 16223 \\
\hline & & Profit per worker & 27.4 & 42.2 & 16223 \\
\hline & & Capital per worker & 339.5 & 607.9 & 16223 \\
\hline & & Employment & 1375.5 & 4602.4 & 16223 \\
\hline & & Turnover & 377028.4 & 1043725.0 & 16207 \\
\hline \multicolumn{6}{|c|}{ Parents } \\
\hline & & Average wage per worker & 57.9 & 737.0 & 8969 \\
\hline & & Profit per worker & 28.1 & 43.9 & 16223 \\
\hline & & Capital per worker & 347.6 & 781.8 & 16223 \\
\hline & & Employment & 52093.2 & 71592.1 & 16223 \\
\hline & & Turnover & 12500000 & $2.45 \mathrm{e}+07$ & 16223 \\
\hline & & Survey year & 2002.2 & 2.7 & 16223 \\
\hline \multicolumn{6}{|l|}{ Distance variables } \\
\hline & & IPR & 0.15 & 0.33 & 15960 \\
\hline & & Technology capability & 0.0027 & 0.2895 & 6837 \\
\hline & & Economic development & 7666.466 & 11042.26 & 16158 \\
\hline & & Common language & 0.19 & 0.40 & 16158 \\
\hline & & Geographic & 3487.29 & 3323.92 & 16158 \\
\hline & & Same sector & 0.08 & 0.27 & 16223 \\
\hline & & Number of affiliates & 196.46 & 191.1 & 16223 \\
\hline
\end{tabular}

Notes: Subsample of 760 multinational parents and their 3587 overseas affiliates, covering 36 countries. All monetary variables are in thousands of euros. 'Profit per worker, parents (affiliates)' is profit per worker of the multinational parents (affiliates). 'Capital per worker, parents (affiliates)' is capital per worker of the multinational parents (affiliates). 'Employment, parents (affiliates)' is number of employees of multinational parents (affiliates). 'Sales, parents (affiliates)' is total sales of the multinational parents (affiliates). 'Average wage, parents (affiliates)' is wage per worker of the multinational parents (affiliates). 'IPR distance' is the distance of the IPR index in Park (2008) between the parent and the affiliate country. 'Technology capability distance' is the distance of technology capability between the parent and affiliate country (share of resident patent applications in the total number of applications.). 'Economic development distance' is the distance of GDP per capita between the parent and affiliate country. 'Same language' is equal to one if the parent and affiliate country have common official of primary language, otherwise is zero. 'Geographic distance' is simple distance between capitals of the parent and affiliate country. 'Same sector' if the firms operate in the same two-digit industry. 
Table 10: Effects of location heterogeneity on rent sharing

\begin{tabular}{|c|c|c|c|c|c|c|c|}
\hline & $(1)$ & $(2)$ & $(3)$ & (4) & (5) & (6) & $\overline{(7)}$ \\
\hline$\overline{\mathrm{IPR}}$ & $\begin{array}{c}-.489^{* * *} \\
(.007)\end{array}$ & & & & & & \\
\hline Technology & & $\begin{array}{c}-.340^{* * *} \\
(.013)\end{array}$ & & & & & \\
\hline Economic & & & $\begin{array}{c}-.486^{* * *} \\
(.006)\end{array}$ & & & & \\
\hline Common language & & & & $\begin{array}{c}.074^{* * *} \\
(.007)\end{array}$ & & & \\
\hline Geographic & & & & & $\begin{array}{c}-.298^{* * *} \\
(.014)\end{array}$ & & \\
\hline Same sector & & & & & & $\begin{array}{c}-.067^{* * *} \\
(.008)\end{array}$ & \\
\hline Number of affiliates & & & & & & & $\begin{array}{l}.006 \\
(.005)\end{array}$ \\
\hline Profit $^{P} * I P R$ & $\begin{array}{c}.026^{* * *} \\
(.006)\end{array}$ & & & & & & \\
\hline Profit ${ }^{P} *$ Technology & & $\begin{array}{l}.013 \\
(.010)\end{array}$ & & & & & \\
\hline Profit ${ }^{P} *$ Economic & & & $\begin{array}{c}.054^{* * *} \\
(.005)\end{array}$ & & & & \\
\hline Profit ${ }^{P} *$ SameLang. & & & & $\begin{array}{c}-.042^{* * *} \\
(.007)\end{array}$ & & & \\
\hline Profit ${ }^{P} *$ Geography & & & & & $\begin{array}{l}-.004 \\
(.009)\end{array}$ & & \\
\hline Profit ${ }^{P} *$ SameSector & & & & & & $\begin{array}{l}-.010 \\
(.007)\end{array}$ & \\
\hline Profit ${ }^{P} *$ Affiliates. & & & & & & & $\begin{array}{c}-.012^{* * *} \\
(.004)\end{array}$ \\
\hline Profit, affiliates & $\begin{array}{c}.041^{* * *} \\
(.007)\end{array}$ & $\begin{array}{c}.028^{* *} \\
(.012)\end{array}$ & $\begin{array}{c}.044^{* * *} \\
(.006)\end{array}$ & $\begin{array}{c}.033^{* * *} \\
(.008)\end{array}$ & $\begin{array}{c}.031^{* * *} \\
(.008)\end{array}$ & $\begin{array}{c}.027^{* * *} \\
(.008)\end{array}$ & $\begin{array}{c}.069^{* * *} \\
(.005)\end{array}$ \\
\hline Capital, affiliates & $\begin{array}{c}.418^{* * *} \\
(.008)\end{array}$ & $\begin{array}{c}.505^{* * *} \\
(.014)\end{array}$ & $\begin{array}{c}.436^{* * *} \\
(.007)\end{array}$ & $\begin{array}{c}.585^{* * *} \\
(.008)\end{array}$ & $\begin{array}{c}.585^{* * *} \\
(.008)\end{array}$ & $\begin{array}{c}.587^{* * *} \\
(.008)\end{array}$ & $\begin{array}{c}.233^{* * *} \\
(.006)\end{array}$ \\
\hline Profit ${ }^{P}$ & $\begin{array}{l}.016^{*} \\
(.009)\end{array}$ & $\begin{array}{l}.027 \\
(.017)\end{array}$ & $\begin{array}{c}-.004 \\
(.009)\end{array}$ & $\begin{array}{l}.020^{*} \\
(.011)\end{array}$ & $\begin{array}{c}.021^{* *} \\
(.011)\end{array}$ & $\begin{array}{c}.021^{* *} \\
(.011)\end{array}$ & $\begin{array}{c}.037^{* * *} \\
(.005)\end{array}$ \\
\hline Capital $^{P}$ & $\begin{array}{l}.009 \\
(.018)\end{array}$ & $\begin{array}{l}.014 \\
(.033)\end{array}$ & $\begin{array}{c}.062^{* * *} \\
(.018)\end{array}$ & $\begin{array}{l}-.010 \\
(.021)\end{array}$ & $\begin{array}{c}-.0005 \\
(.021)\end{array}$ & $\begin{array}{c}-.008 \\
(.021)\end{array}$ & $\begin{array}{l}.009^{*} \\
(.006)\end{array}$ \\
\hline Obs. & 15960 & 6837 & 16158 & 16158 & 16158 & 16223 & 16223 \\
\hline$F$ statistic & 881.488 & 246.602 & 1057.037 & 483.931 & 510.285 & 477.261 & 442.038 \\
\hline$R^{2}$ & .678 & .658 & .708 & .587 & .595 & .584 & .781 \\
\hline
\end{tabular}

Notes: Dependent variable: log of wage per worker in each affiliate. Sample of 760 multinationals (from 25 countries) and their 3587 overseas affiliates (36 countries). Each multinational parent has overseas affiliates at least in two different countries. All specifications control for parent firm fixed effects and year effects. All firm characteristics variables are in logarithms. Values in parentheses are standard errors. See the notes to Table 9 for more details. Significance levels: *: $0.10 ; * *: 0.05 ; * * *: 0.01$. 
Table 11: Effects of location heterogeneity on rent sharing (using weights based on parent country FDI)

\begin{tabular}{|c|c|c|c|c|c|c|c|}
\hline & $(1)$ & $(2)$ & $(3)$ & $(4)$ & $(5)$ & $(6)$ & $(7)$ \\
\hline$\overline{\mathrm{IPR}}$ & $\begin{array}{c}-.539^{* * *} \\
(.007)\end{array}$ & & & & & & \\
\hline Technology & & $\begin{array}{c}-.348^{* * *} \\
(.014)\end{array}$ & & & & & \\
\hline Economic & & & $\begin{array}{c}-.529^{* * *} \\
(.007)\end{array}$ & & & & \\
\hline Same language & & & & $\begin{array}{l}.004 \\
(.006)\end{array}$ & & & \\
\hline Geographic & & & & & $\begin{array}{c}-.557^{* * *} \\
(.018)\end{array}$ & & \\
\hline Same sector & & & & & & $\begin{array}{c}-.132^{* * *} \\
(.010)\end{array}$ & \\
\hline Number of affiliates & & & & & & & $\begin{array}{l}.002 \\
(.006)\end{array}$ \\
\hline $\operatorname{Profit}^{P} * I P R$ & $\begin{array}{c}.043^{* * *} \\
(.006)\end{array}$ & & & & & & \\
\hline Profit ${ }^{P} *$ Technology & & $\begin{array}{l}.022^{*} \\
(.011)\end{array}$ & & & & & \\
\hline Profit $^{P} *$ Economic & & & $\begin{array}{c}.072^{* * *} \\
(.005)\end{array}$ & & & & \\
\hline Profit ${ }^{P} *$ SameLang. & & & & $\begin{array}{c}-.032^{* * *} \\
(.006)\end{array}$ & & & \\
\hline Profit $^{P} *$ Geography & & & & & $\begin{array}{l}-.005 \\
(.010)\end{array}$ & & \\
\hline Profit ${ }^{P} *$ SameSector & & & & & & $\begin{array}{c}-.031^{* * *} \\
(.009)\end{array}$ & \\
\hline Profit ${ }^{P} *$ Affiliates & & & & & & & $\begin{array}{c}-.028^{* * *} \\
(.005)\end{array}$ \\
\hline Profit, affiliates & $\begin{array}{l}.037^{* * *} \\
(.006)\end{array}$ & $\begin{array}{l}.034^{* * *} \\
(.012)\end{array}$ & $\begin{array}{c}.051^{* * *} \\
(.006)\end{array}$ & $\begin{array}{c}.023^{* * *} \\
(.008)\end{array}$ & $\begin{array}{l}.024^{* * *} \\
(.007)\end{array}$ & $\begin{array}{c}.021^{* * *} \\
(.007)\end{array}$ & $\begin{array}{c}.077^{* * * *} \\
(.005)\end{array}$ \\
\hline Capital, affiliates & $\begin{array}{c}.379^{* * *} \\
(.008)\end{array}$ & $\begin{array}{l}.493^{* * *} \\
(.014)\end{array}$ & $\begin{array}{c}.387^{* * *} \\
(.007)\end{array}$ & $\begin{array}{c}.549^{* * *} \\
(.009)\end{array}$ & $\begin{array}{c}.533^{* * *} \\
(.008)\end{array}$ & $\begin{array}{c}.544^{* * *} \\
(.008)\end{array}$ & $\begin{array}{c}.200^{* * *} \\
(.006)\end{array}$ \\
\hline Profit ${ }^{P}$ & $\begin{array}{l}.005 \\
(.009)\end{array}$ & $\begin{array}{l}.025 \\
(.019)\end{array}$ & $\begin{array}{l}-.014 \\
(.009)\end{array}$ & $\begin{array}{l}.021^{*} \\
(.011)\end{array}$ & $\begin{array}{l}.021^{*} \\
(.012)\end{array}$ & $\begin{array}{l}.017 \\
(.011)\end{array}$ & $\begin{array}{c}.054^{* * *} \\
(.005)\end{array}$ \\
\hline Capital $^{P}$ & $\begin{array}{l}.012 \\
(.020)\end{array}$ & $\begin{array}{l}.017 \\
(.038)\end{array}$ & $\begin{array}{c}.069^{* * *} \\
(.020)\end{array}$ & $\begin{array}{r}-.017 \\
(.023)\end{array}$ & $\begin{array}{l}-.001 \\
(.023)\end{array}$ & $\begin{array}{l}-.013 \\
(.023)\end{array}$ & $\begin{array}{c}.031^{* * *} \\
(.006)\end{array}$ \\
\hline Obs. & 15960 & 6837 & 16158 & 16158 & 16158 & 16192 & 16192 \\
\hline$F$ statistic & 846.596 & 220.951 & 926.26 & 393.435 & 474.862 & 408.47 & 408.774 \\
\hline$R^{2}$ & .67 & .642 & .683 & .553 & .58 & .558 & .767 \\
\hline
\end{tabular}

Notes: Dependent variable: log of wage per worker in each affiliate. Sample of 760 multinationals (from 25 countries) and their 3,587 overseas affiliates (36 countries). All specifications control for parent firm fixed effect and business cycle effects. See notes to Table 10 for more details. Significance levels: *: 0.10; **: 0.05; ***: 0.01 . 